Expl Cell Biol 1989;57:I-V

\title{
Contents, Vol. 57, 1989
}

International Journal of Basic Pathology, Neoplasia, Differentiation,

Immunology and Heterotransplantation

Founded 1938 as 'Schweizerische Zeitschrift fur allgemeine Pathologie und

Bakteriologie' by A. v. Albertini, A. Grumbach and H. Mooser,

continued as 'Pathologia et Microbiologia'

Editors Co-Editors

Pathology Pathology Differentiation

J.R. Rüttner, Zurich R. Hess, Berne B.M. Carlson, Ann Arbor, Mich.

Neoplasia, Differentiation, General M. Kyogoku, Sendai G.M.W. Cook, Cambridge

and Tumor Immunology M.A. Spycher, Zurich U. Drews, Tubingen

G.V. Sherbet, Newcastle upon Tyne P. Vassalli, Geneva M. Feldman, Rehovot

Heterotransplantation G. Zbinden, Zurich D.R. Garrod, Southampton

L. Helson, Valhalla, N.Y. N 1 - C. Graham, Oxford

$>$-. $\gamma \mathrm{n} \tau>-\wedge_{\mathrm{i}} \mathrm{JR}$. Harris, Brentwood, Essex G.D. Birnie, Glasgow _ ._.. $\tau$, D r, ,-, ¿ $\mathrm{o}^{\circ}$.. P.A.

Riley, London R.C. Coombes, Sutton “

D. Glaves Rapp, Buffalo, N.Y. Heterotransplantation

I.R. Hart, London B.C. Giovanella, Houston, Tex.

K. Hellmann, London D.P. Houchens, Columbus, Ohio

M.S. Lakshmi, Newcastle upon Tyne I. Lefkovits, Basel

C.J. Marshall, London T. Nomura, Kanagava

L. Milas, Houston, Tex. CO. Poulsen, Copenhagen

G.L. Nicolson, Houston, Tex. N.D. Reed, Bozeman, Mont.

G. Poste, Philadelphia, Pa. J. Rygaard, Copenhagen

P.S. Rudland, Liverpool S. Shin, Bronx, N.Y.

V. Schirrmacher, Heidelberg B.C.M. Sordat, Lausanne

J.-C. Salomon, Villejuif

E. Sidebottom, Oxford

D. Tarin, Oxford

S. Karger $\cdot$ Medical and Scientific Publishers

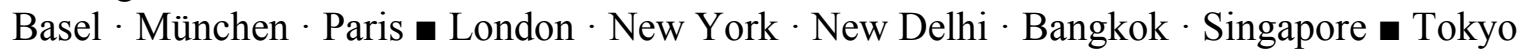
Sydney

Drug Dosage

The authors and the publisher have exerted every effort to ensure that drug selection and dosage set forth in this text are in accord with current recommendations and practice at the time of publication. However, in view of ongoing research, changes in government regulations, and the constant flow of information relating to drug therapy and drug reactions, the reader is urged to check the package insert for each drug for any change in indications and dosage and for added 
warnings and precautions. This is particularly important when the recommended agent is a new and/or infrequently employed drug.

All rights reserved.

No part of this publication may be translated into other languages, reproduced or utilized in any form or by any means, electronic or mechanical, including photocopying, recording, microcopying, or by any information storage and retrieval system, without permission in writing from the publisher or, in the case of photocopying, direct payment of a specified fee to the Copyright Clearance Center (see 'Information for Readers and Subscribers').

C Copyright 1989 by

S. Karger AG, P.O. Box, CH-4009 Basel (Switzerland) Printed in Switzerland by Thiir AG Offsetdruck, Pratteln

Contents Vol. 57,1989

No. 1 Cell Surface Changes during Electromagnetic Field Exposure

Hamada, S.H.; Witkus, R.; Griffith, R., Jr 1

Variations in WGA-Binding Proteins in Tumours Growing in Different Implantation

Sites

Chan, W.-S.; Page, CM.; Turner, G.A

Partial Purification of Human Urinary Megakaryocyte Colony-Stimulating Factor

Ogata, K.; Kuriya, S.; Dan, K.; Nomura, T 19

Further Characterization of the Biological Properties of Human Hematopoietic Survival

and Growth Factor

Hiraoka, A.; Ohkubo, T.; Fukuda, M 27

Detection of Receptor-Mediated Membrane Effects of Dexamethasone in B16 Murine Melanoma Cell Lines by Cell Partitioning in Aqueous Two-Polymer Systems

Risely, G.P.; Sherbet, GV 35

Electrically Regulated Cellular Morphological and Cytoskeletal Changes on an Optically

Transparent Electrode (with 1 color plate)

Yaoita, M.; Aizawa, M.; Ikariyama, Y

Book Review 52

Announcement 52

No. 2 Cytotoxicity of N6-Cycloalkylated Adenine and Adenosine Analogs to Mouse Hepatoma Cells

Thedford, R.; Leyimu, E.O.; Thornton, D.L.; Metha, R 53

Cohesive Properties of Terminally Differentiated Keratinocytes

Brysk, M.M.; Rajaraman, S.; Penn, P.; Barlow, E.; Bell, T 60

Differences in Intracellular Calcium Mobilization by Interferon- $\beta$ and Interferon- $\gamma$ in

RPMI-4788 Cells

Miyake, M.; Fuchimoto, S.; Orita, K 67

Behavior of in vitro Grown Normal Human Mucosal Epithelial Cells and Tumorigenic Rat

Cells Inoculated into Nude Mice

Holmstrup, P.; Arenholt-Bindslev, D.; Jepsen, A.; Stoltze, K

Abstracts

Third Symposium of the Upper Rhine Universities

Freiburg i. Brsg., FRG, April 14-15, 198981

No. 3 Enhanced Survival of Motoneurons in the Chick Lateral Motor Column: Effects of Embryonic Skeletal Muscle Extracts and Myoblast-Conditioned Medium 
Petruzzelli, G; Hughes, W.F 125

Expression of the Plasma Membrane Proteolipid in Mouse Neuroblastoma Cells: Transient Increase in Synthesis during Differentiation with N6,02-Dibutyryl Adenosine 3',5'-

Cyclic Monophosphate

Shea, T.B.; Fischer 1131

IV Contents

Mitogenic Effect of Estradiol on MCF-7 Human Breast Cancer Cells Can Be Modulated by Serum

Najid, A.; Nicolas, A.; Tixier, M.; Habrioux, G

Differential Adhesion of Metastatic Rat Mammary Carcinoma Cells to Organ-Derived

Microvessel Endothelial Cells and Subendothelial Matrix

Lichtner, R.B.; Belloni, P.N.; Nicolson, G.L 146

Expression of Lewis Antigenic Determinants in Colorectal Adenocarcinomas (with 1 color plate)

Blasco, E.; Torrado, J.; Cosme, A.; Alvarez, E.; Zugasti, A.; Gutierrez-Hoyos, A.;

Arenas, J.I 153

Activities of Glycolytic Enzymes in Rapidly Proliferating and Differentiated C6 Glioma

Cells

Dastidar, S.G.; Sharma, S.K 159

The Role of Laminin in Cancer Invasion and Metastasis

Hunt, G $\quad 165$

No. 4 Immunoglobulin and T Cell Receptor Gene Rearrangements in Lymphoproliferative Dis

orders

Daus, H.; Schwarze, G.; Pees, H.; Radtke, H.; Kümel, G.; Scheurlen, P.G 177

Characterization and Differential Expression of an Endothelial Cell-Specific Surface Antigen in

Continuous and Sinusoidal Endothelia, in Skin Vascular Lesions and in vitro (with 1 color plate)

Goerdt, S.; Steckel, F.; Schulze-Osthoff, K.; Hagemeier, H.-H.; Macher, E.; Sorg, C. . 185

Putative Mesothelial Cell Growth-Promoting Activity of a Cytoplasmic Protein Expressed by the

Mesothelial Cell. A Preliminary Report (with 1 color plate) Donna, A.; Betta, P.-G.; Cosimi,

M.F.; Robutti, F.; Bellingeri, D.; Marchesini, A. . 193

Membrane Fluidity and Cancer Metastasis

Sherbet, G.V 198

Effects of TGF-Beta on Retinal Pigmented Epithelium in vitro

Opas, M.; Dziak, E 206

In vitro Interaction of Heterologous Platelets with Isolated Neoplastic Cells from a Murine

Mammary Gland Tumor

Eynard, A.R.; Falo, C; Quiroga, P.; Pasqualini, M.E 213

Vascularization of Ovaries from Golden Hamsters Following Implantation into the Chick

Chorioallantoic Membrane

Spanel-Borowski, K 219

Erratum 228

No. 5 Fibronectin Content of the Annulus fibrosus in Diabetic and Non-Diabetic Sand Rats

Silberberg, R.; Meier-Ruge, W.; Odermatt, B 229

Age-Related Changes in Fibronectin in Annulus fibrosus of the Sand Rat (Psammomys

obesus)

Silberberg, R.; Meier-Ruge, W.; Odermatt, B 
Time-Based Changes in Fibroblast Three-Dimensional Locomotory Characteristics and Phenotypes

Noble, P.B.; Shields, E.D 238

Contents

$\mathrm{V}$

Nodular Organization and Differential Intrametastatic Distribution of the Fluorescent Dye Hoechst 33342 in B16 Melanoma Liver Metastasis

Aliño, S.F.; Hilario, E 246

Changes in Collagen Synthesis by Human Bone Marrow Fibroblasts with Progressive

Subcultivation

Fernandez, M.; Barahona, C; Martinez, J.; Minguell, J.J 257

Studies on Thymocyte Subpopulations in Guinea Pigs. X. Rosette-Forming Ability of

Thymocyte Subpopulations before and after Incubation in vitro

Kölare, S.; Sandberg, G 264

Attempted Modulation of Disulfide Antitumor Activity in Balb/c Mice through Gluta-

thione Depletion

Coshan-Gauthier, R.K.; Kirkpatrick, D.L 273

No. 6 Review of the Significance of Pulmonary Intravascular Macrophages with Respect to Animal Species and Age

Winkler, G.C 281

Formation of Double Contour as a Repair Reaction in the Human Femoral Head

Lothe, K.; Spycher, M.A 287

Generalized Cutaneous Hyperpigmentation in Hairless Mice Induced by Topical Dimethylbenzanthracene

Tsambaos, D.; Sampalis, F.; Berger, H 292

Phagocytic Properties of Hepatic Endothelial Cells and Splenic Macrophages Compensating for a Decreased Phagocytic Function of Kupffer Cells in the Chronically Ethanol-

Fed Rats

Shiratorí, Y.; Jin'nai, H.; Teraoka, H.; Matano, S.; Matsumoto, K.; Kamii, K.; Tanaka, M.;

Okano, K 300

Hypoxic Injury of Rat Cortical Neurons in Primary Cell Cultures. Introduction of a Modified

Method to Create the Hypoxic State

Kinoshita, A.; Yamada, K.; Hayakawa, T 310

Interaction between Endothelial Cells and Basement Membrane Components. In vitro Studies

on Endothelial Cell Adhesion to Collagen Types I, III, IV and High Molecular Weight

Fragments of IV

Rixen, H.; Kirkpatrick, C.J.; Schmitz, U.; Ruchatz, D.; Mittermayer, C 315

Alkaline Phosphatase Expression in Human Cell Lines Derived from Primary Hepatomas

Tokiwa, T.; Endo, A.; Sato, J 324

Immunolocalization of a Subnucleolar Nucleoprotein Complex Containing RNA Poly-

merase 1 in Ascites Hepatoma Cells Using Monoclonal Antibodies

Rosenberg, N.L.; Nicolson, G.L 330

Nuclear Retinoic-Acid-Binding Proteins and Receptors in Retinoic-Acid-Responsive Cell Lines Daly, A.K.; Rees, J.L.; Redfern, C.P.F 339

In vitro Proliferation of Murine Spleen Cells: Inhibition by Monoclonal Antibodies to L3T4 and Lyt-2 T Cell Markers or Intracellular Cyclic Adenosine Monophosphate 
Zhou, P.; Gorzynski, T.; Dowjat, W.K.; Rabin, R.; Zaleski, M.B 346

Publisher's Note 358

Acknowledgments

360

Announcements

361

Author Index

362

Subject Index

365 